\title{
Molecular Analysis of Peritoneal Fluid in Ovarian Cancer Patients
}

Paola Parrella, M.D., Rachel Zangen, M.D., David Sidransky, M.D., Theresa Nicol, M.D.

Department of Otolaryngology_Head and Neck Surgery, Head and Neck Cancer Research Division (PP, RZ, DS) and Department of Pathology (TN), Johns Hopkins University School of Medicine, Baltimore, Maryland and Laboratorio di Patologia Molecolare e Terapia Genica, IRCCS "Casa Sollievo della Sofferenza," Foggia, Italy (PP)

To determine whether genetic abnormalities present in primary ovarian tumors can be used to detect cancer cells in peritoneal fluid, we tested 14 ovarian cancers and 1 benign tumor of the ovary for loss of heterozygosity ( $\mathrm{LOH})$ at chromosomal arms $13 q, 17 p, 17 q$, and $22 q$ and for mutations in the $p 53$ and $K$-ras genes. In each case, matched primary tumor, normal tissue, and peritoneal fluid were analyzed. The highest frequency of $\mathrm{LOH}$ was found on chromosomal arm 17p (42\%), followed by chromosomal arm 17q (36\%), 22q (30\%), and 13q (21\%). Identical alterations were detected in matched peritoneal fluid (either peritoneal wash or ascitic fluid) in 3 of the 8 patients with LOH in the tumor (38\%). Direct sequence analysis detected p53 mutations in 3 of the 14 malignant tumors (21\%) and no (0) $\mathrm{K}$-ras mutations. Identical mutations were detected in matched peritoneal fluid from all 3 patients with p53 mutations. All 8 of the 14 (57\%) malignant tumors that showed at least one genetic abnormality were serous adenocarcinoma and identical alterations were detected in 5 of the $8(62 \%)$ matched peritoneal fluid samples. Our findings indicate that molecular abnormalities can be detected in peritoneal fluid from patients with ovarian cancer and may be used to complement current conventional diagnostic procedures for detection of primary ovarian cancer.

KEY WORDS: Cytology, K-ras, Microsatellite, Mo-

\footnotetext{
Copyright () 2003 by The United States and Canadian Academy of Pathology, Inc.

VOL. 16, NO. 7, P. 636, 2003 Printed in the U.S.A.

Date of acceptance: April 10, 2003.

This work was supported by NCI Grant (1 U01 CA84986) part of the Early Detection Research Network. It was also supported by Progetto Ministero della Salute IRCCS, (RC-2001, 2002), Italy.

Address reprint requests to: Theresa Nicol, M.D., Dept. of Otolaryngology-Head \& Neck Surgery, The Johns Hopkins University School of Medicine, 818 Ross Research Building, 720 Rutland Avenue, Baltimore, MD 21205-2196; fax: 410-614-1411; e-mail: tnicol@jhmi.edu.

DOI: 10.1097/01.MP.0000076979.28106.ED
}

lecular detection, Ovarian cancer, p53, Peritoneal fluid.

Mod Pathol 2003;16(7):636-640

Ovarian cancer is the fifth leading cause of cancer incidence and the most common cause of death from gynecological malignancies in the Western World (1). The asymptomatic onset and insidious progression of this disease accounts for the frequently advanced stage at time of diagnosis. Only about $24 \%$ of all the cases are detected at the localized stage (2). Cytological examination of peritoneal fluid was first proposed in 1956 as a means of detecting sub clinical metastases (3). Subsequently, the International Federation of Gynecologists and Obstetricians (FIGO) has incorporated peritoneal fluid cytology into its protocol for the staging of ovarian cancer (4). However, both false-negative and false-positive rates of peritoneal fluid cytology are high (5). Because the presence of malignant cells in the peritoneal fluid is an important prognostic indicator, there is a critical need for new diagnostic methods able to improve our ability to detect microscopic disease in the peritoneal cavity.

Although the molecular mechanisms that underlie the development and progression of ovarian cancer are poorly understood, several genetic abnormalities have been reported. Loss of heterozygosity involving BRCA1 $(6,7), B R C A 2(8)$, and $22 \mathrm{q}$ (9) loci have been found in $25-67 \%$ of epithelial tumors, $K$-ras mutations in $35-85 \%(10,11)$, and p53 mutations in 35-60\%, depending on tumor type and the source of the data (7, 9-14). Germline mutations in the BRCA1 and BRCA2 genes are thought to be responsible for most cases of hereditary ovarian cancer, but only a few mutations have been detected in sporadic tumors $(6-8,15,16)$.

To determine whether genetic abnormalities present in primary ovarian tumors can be detected in peritoneal fluid, 15 cases (14 malignant and 1 benign tumor) were analyzed for loss of heterozygosity (LOH) using seven microsatellite markers on 
chromosomal arms 13q, 19p, 19q, and $22 \mathrm{q}$ and mutations in the $p 53$ and $K$-ras genes. Abnormalities for at least one marker were detected in 8 of the $14(57 \%)$ malignant tumors, and identical changes were detected in 5 of 8 (62\%) matched peritoneal fluid samples.

\section{MATERIALS AND METHODS}

\section{Specimens and DNA Extraction}

Primary tumors and normal (blood lymphocytes or normal ovarian tissues) and cytological samples from 15 cases were collected from The Johns Hopkins Ovarian Cancer Tumor Registry between July 1999 and March 2000. The ovarian tumors included nine serous carcinomas, two endometrioid carcinomas (one with a yolk sac tumor component), one clear cell carcinoma, one small cell carcinoma, one mucinous atypical proliferating tumor (low malignant potential), and one cystadenofibroma (Fig. 1). Matched normal control tissue and either pelvic wash $(n=12)$ or ascitic fluid $(n=3)$ were available for each case (Table 1). Frozen tumor specimens were microdissected on a cryostat so that the tumor samples contained $\geq 70 \%$ neoplastic cells. DNA was extracted from paired normal, tumor, and peritoneal fluid as described previously (17).

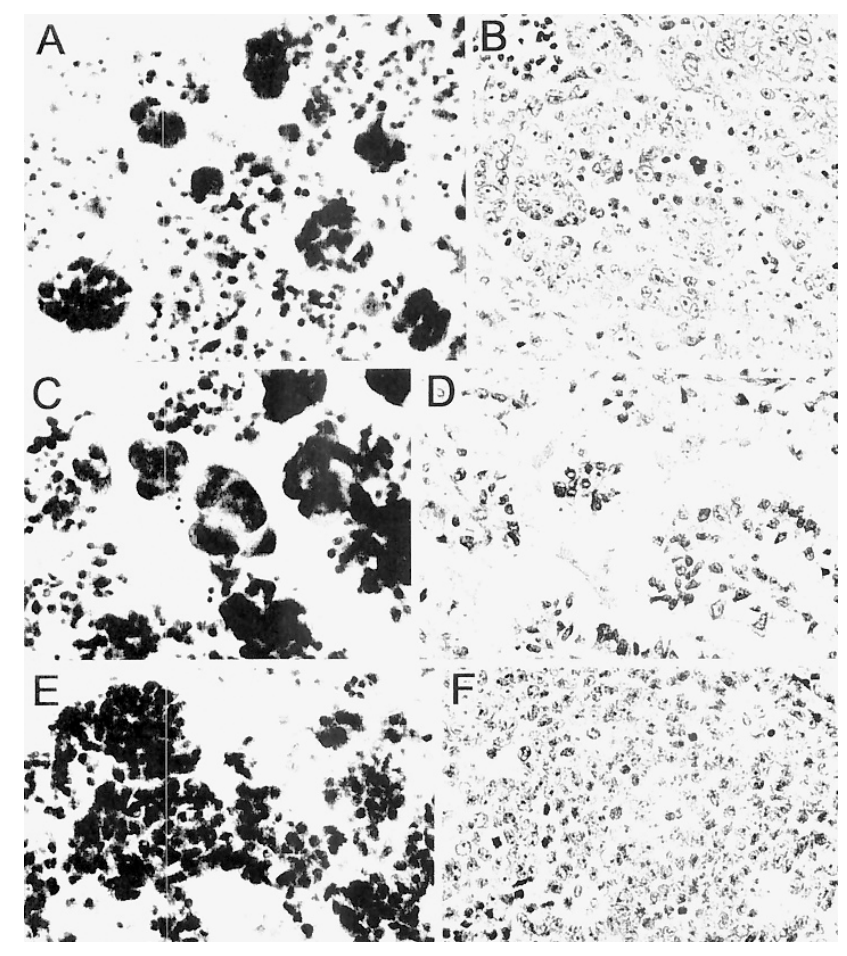

FIGURE 1. Cytology and histology of representative cases. (1) Papillary serous carcinoma of the ovary. Pelvic wash (A; Papanicolaou stain, $160 \times$ ) and ovary (B; H\&E stain, 160×). (2) Clear cell carcinoma of the ovary. Pelvic wash (C; Papanicolaou stain, $240 \times$ ) and ovary (D; H\&E, 240×). (3) Small cell carcinoma of the ovary. Pelvic wash (E; Papanicolaou stain, $160 \times$ ) and ovary (F; H\&E, 160×).
Microsatellite Markers Analysis

To detect $\mathrm{LOH}$ in primary ovarian cancer and matched peritoneal fluid DNA from normal, tumor samples, and ascite or pelvic wash (Table 1) were analyzed by PCR. Primer pairs (Research Genetics Huntsville, AL) amplifying seven microsatellite markers mapped to chromosomal arms 17 (D17S579, D17S855, D17S786), 13q (D13S260, D13S267), and 22q (IL2RB, D22S283) were used. PCR conditions included a denaturation step for 2 minutes at $95^{\circ} \mathrm{C}$, followed by 35 cycles at $95^{\circ} \mathrm{C}$ for 1 minute, $54-58^{\circ} \mathrm{C}$ for 1 minute, $72^{\circ} \mathrm{C}$ for 1 minute, and by a final 4 -minute extension at $72^{\circ} \mathrm{C}$. About one quarter of the PCR product was separated on 8 M urea-formamide-polyacrylamide gel and exposed to film. For each microsatellite marker, the $\mathrm{LOH}$ ratio was calculated as a percentage of the number of tumors, with allelic loss divided by the number of informative cases. Tumor samples were considered positive for $\mathrm{LOH}$ if they harbored allelic loss in at least one microsatellite marker $(18,19)$.

\section{p53 and K-ras Amplification and Sequencing}

The $K$-ras gene and a fragment containing the exons 4 through 8 of the $p 53$ gene were amplified as described previously (20). The analysis was carried out using Thermosequenase (Perkin-Elmer, Roche Molecular Systems, Inc., Branchburg, NJ) with cycle conditions according to the manufacturer's instruction. Sequencing products were separated on a Genomyx electrophoresis apparatus (Beckman Coulter Inc., Fullerton, CA). For samples with mutations, the analysis was repeated in two independent PCR and sequencing reactions.

\section{Oligonucleotide Mismatch Ligation Assay}

To detect p53 mutations in DNA extracted from peritoneal fluids, fragments containing mutations were PCR amplified and ethanol precipitated. For each mutation, discriminating oligonucleotides that contained the mutated base at the 3 ' end were designed. Immediately adjacent $\left[{ }^{32} \mathrm{P}\right] 3^{\prime}$ sequences were used as substrate, together with discriminating oligonucleotides (Life Technologies, Rockville, $\mathrm{MD})$ for the ligation reaction. After a denaturing step at $95^{\circ} \mathrm{C}$ for 5 minutes, the reactions were incubated for 1 hour at $37^{\circ} \mathrm{C}$ in the presence of $\mathrm{T} 4$ DNA ligase (Life Technologies) and analyzed in denaturing $15 \%$ polyacrylamide gels (21).

\section{RESULTS}

We analyzed 14 malignant ovarian tumors and matched peritoneal fluid for $\mathrm{LOH}$ at seven microsatellite markers and at mutations in the $K$-ras and p53 genes. The seven microsatellite markers were 
chosen to map on chromosomal arms 13q (BRCA2 locus), $17 \mathrm{p}$ and $\mathrm{q}$ (BRCA1 and p53 loci), and 22q. The highest frequency of LOH was found on chromosomal arm 17p (42\%), followed by chromosomal arms $17 q(36 \%), 22 q(30 \%)$, and $13 q(21 \%)$. The same alterations were detected in matched peritoneal fluid in three of the eight patients with LOH in the tumor (38\%; Table 1). Representative results are shown in Figure 2A.

Direct manual sequence analysis of the $p 53$ gene detected mutations in 3 of the 14 malignant tumors (21\%). Two of those mutations were frameshift mutations, an insertion CC in exon 6 (tumor OC1) and a 17-bp deletion in exon 5 (tumor OC13). The third mutation was a C $224 \mathrm{~T}$ transversion in exon 7 that changed codon 248 from Arg to Trp in tumor OC17. Identical mutations were detected by our mismatch ligation assay in matched peritoneal fluids from all 3 patients with p53 mutations (100\%; Table 1; Fig. 2B-C). No mutations were detected in the $K$-ras gene either by direct manual sequence analysis or oligonucleotide mismatch ligation assay (data not shown).

In total 8 of the $14(57 \%)$ malignant tumors showed at least one genetic alteration (either p53 mutations or LOH). Remarkably, all of them were of the serous adenocarcinoma subtype. Moreover, identical alterations were detected in 5 of the 8 $(62 \%)$ matched peritoneal fluid samples. Of these positive fluids, three were from ascites (OC2, OC13 and $\mathrm{OC} 17)$ and two from peritoneal washes (OC1 and OC6; Table 1). Tumor OC13 showed LOH at four microsatellite markers including D17S786 and harbored a $p 53$ mutation, and both changes were detectable in the peritoneal fluid. We did not find genetic abnormalities in either the tumor of low malignant potential or the only benign tumor tested (Table 1). In our series, seven of the eight tumors with molecular abnormalities were also positive by cytological examination (Table 1). In one patient with microsatellite alterations in microsatellite markers in the primary tumor, the cytopathological diagnosis was equivocal. In this case we were also unable to detect $\mathrm{LOH}$ in the peritoneal fluid, a relatively insensitive detection approach.

\section{DISCUSSION}

The understanding of the molecular genetic changes associated with cancer has led to the de-

TABLE 1. Loss of Heterozygosity Detected in Primary Ovarian Cancer and Corresponding Peritoneal Fluid

\begin{tabular}{|c|c|c|c|c|c|c|c|c|c|c|c|c|}
\hline & \multirow{2}{*}{ Pathology ${ }^{\mathrm{a}}$} & \multirow{2}{*}{ Stage } & \multirow{2}{*}{ Cytology $^{\mathrm{b}}$} & \multirow{2}{*}{ Sample ${ }^{\mathrm{c}}$} & \multicolumn{2}{|c|}{ BRCA1 } & \multicolumn{2}{|c|}{ BRCA2 } & \multicolumn{2}{|c|}{$22 q$} & P53 & \multirow{2}{*}{ P53 Mutations ${ }^{\mathrm{e}}$} \\
\hline & & & & & D17S579d & $17 \mathrm{~S} 855^{\mathrm{d}}$ & D13S260 & $\mathrm{D} 13 \mathrm{~S} 267^{\mathrm{d}}$ & D17S786 & $\mathrm{D} 22 \mathrm{~S} 283^{\mathrm{d}}$ & D17S786 ${ }^{d}$ & \\
\hline \multirow[t]{2}{*}{ OC2 } & Serous ca & IIIC & + & $\mathrm{T}$ & $\mathrm{R}$ & $\mathrm{LOH}$ & $\mathrm{R}$ & $\mathrm{R}$ & $\mathrm{R}$ & $\mathrm{R}$ & $\mathrm{LOH}$ & Neg \\
\hline & & & & A & $\mathrm{R}$ & $\mathrm{LOH}$ & $\mathrm{R}$ & $\mathrm{R}$ & $\mathrm{R}$ & $\mathrm{R}$ & $\mathrm{LOH}$ & N/A \\
\hline \multirow[t]{2}{*}{ OC9 } & Serous ca & IIIC & + & $\mathrm{T}$ & $\mathrm{LOH}$ & $\mathrm{R}$ & ni & $\mathrm{LOH}$ & $\mathrm{R}$ & $\mathrm{R}$ & $\mathrm{R}$ & Neg \\
\hline & & & & $\mathrm{W}$ & $\mathrm{LOH}$ & $\mathrm{R}$ & ni & $\mathrm{LOH}$ & $\mathrm{R}$ & $\mathrm{R}$ & $\mathrm{R}$ & N/A \\
\hline \multirow[t]{2}{*}{ OC13 } & Serous ca & IIIC & + & $\mathrm{T}$ & $\mathrm{LOH}$ & $\mathrm{LOH}$ & $\mathrm{R}$ & ni & $\mathrm{R}$ & $\mathrm{LOH}$ & $\mathrm{LOH}$ & Exon 5785 bp del 17 bp \\
\hline & & & & A & $\mathrm{LOH}$ & $\mathrm{LOH}$ & $\mathrm{R}$ & $\mathrm{Ni}$ & $\mathrm{R}$ & $\mathrm{LOH}$ & $\mathrm{LOH}$ & POS \\
\hline \multirow[t]{2}{*}{$\mathrm{OC} 1$} & Serous ca & IIIC & + & $\mathrm{T}$ & $\mathrm{R}$ & ni & ni & $\mathrm{R}$ & ni & $\mathrm{LOH}$ & $\mathrm{LOH}$ & Exon 6835 bp InsCC \\
\hline & & & & $\mathrm{W}$ & $\mathrm{R}$ & ni & ni & $\mathrm{R}$ & ni & $\mathrm{R}$ & $\mathrm{R}$ & POS \\
\hline \multirow[t]{2}{*}{ OC17 } & Serous ca & IV & + & $\mathrm{T}$ & $\mathrm{R}$ & $\mathrm{R}$ & ni & $\mathrm{R}$ & ni & $\mathrm{R}$ & $\mathrm{LOH}$ & Exon 7991 bp $\mathrm{C} \rightarrow \mathrm{T}$ \\
\hline & & & & A & $\mathrm{R}$ & $\mathrm{R}$ & ni & $\mathrm{R}$ & ni & $\mathrm{R}$ & $\mathrm{R}$ & POS \\
\hline \multirow[t]{2}{*}{ OC6 } & Serous ca & IIIC & atypical & $\mathrm{T}$ & $\mathrm{LOH}$ & $\mathrm{R}$ & $\mathrm{LOH}$ & NI & $\mathrm{LOH}$ & $\mathrm{R}$ & $\mathrm{LOH}$ & Neg \\
\hline & & & & $\mathrm{W}$ & $\mathrm{R}$ & $\mathrm{R}$ & $\mathrm{R}$ & $\mathrm{NI}$ & $\mathrm{R}$ & $\mathrm{R}$ & $\mathrm{R}$ & N/A \\
\hline \multirow[t]{2}{*}{$\mathrm{OC} 7$} & Serous ca & IIIC & + & $\mathrm{T}$ & ni & $\mathrm{LOH}$ & $\mathrm{R}$ & ni & $\mathrm{R}$ & $\mathrm{LOH}$ & ni & Neg \\
\hline & & & & $\mathrm{W}$ & ni & $\mathrm{R}$ & $\mathrm{R}$ & ni & $\mathrm{R}$ & $\mathrm{R}$ & ni & N/A \\
\hline \multirow[t]{2}{*}{ OC15 } & Serous ca & IIC & + & $\mathrm{T}$ & $\mathrm{LOH}$ & $\mathrm{LOH}$ & NI & $\mathrm{LOH}$ & ni & $\mathrm{LOH}$ & ni & Neg \\
\hline & & & & $\mathrm{W}$ & $\mathrm{R}$ & $\mathrm{R}$ & NI & $\mathrm{R}$ & ni & $\mathrm{R}$ & ni & N/A \\
\hline \multirow[t]{2}{*}{ OC8 } & Serous ca & IIIA & + & $\mathrm{T}$ & $\mathrm{R}$ & $\mathrm{R}$ & $\mathrm{R}$ & $\mathrm{R}$ & $\mathrm{R}$ & $\mathrm{R}$ & $\mathrm{R}$ & Neg \\
\hline & & & & $\mathrm{W}$ & $\mathrm{R}$ & $\mathrm{R}$ & $\mathrm{R}$ & $\mathrm{R}$ & $\mathrm{R}$ & $\mathrm{R}$ & $\mathrm{R}$ & N/A \\
\hline \multirow[t]{2}{*}{ OC10 } & Mucinous LMP & IA & - & $\mathrm{T}$ & $\mathrm{R}$ & $\mathrm{R}$ & $\mathrm{R}$ & $\mathrm{R}$ & $\mathrm{R}$ & $\mathrm{R}$ & $\mathrm{R}$ & Neg \\
\hline & & & & $\mathrm{W}$ & $\mathrm{R}$ & $\mathrm{R}$ & $\mathrm{R}$ & $\mathrm{R}$ & $\mathrm{R}$ & $\mathrm{R}$ & $\mathrm{R}$ & N/A \\
\hline \multirow[t]{2}{*}{ OC12 } & Small cell Ca & IIIB & + & $\mathrm{T}$ & $\mathrm{R}$ & $\mathrm{R}$ & ni & $\mathrm{R}$ & $\mathrm{R}$ & $\mathrm{R}$ & $\mathrm{R}$ & Neg \\
\hline & & & & $\mathrm{W}$ & $\mathrm{R}$ & $\mathrm{R}$ & ni & $\mathrm{R}$ & $\mathrm{R}$ & $\mathrm{R}$ & $\mathrm{R}$ & N/A \\
\hline \multirow[t]{2}{*}{ OC14 } & Endometrioid ca & IA & - & $\mathrm{T}$ & $\mathrm{R}$ & ni & ni & $\mathrm{R}$ & $\mathrm{R}$ & $\mathrm{R}$ & $\mathrm{R}$ & Neg \\
\hline & & & & $\mathrm{W}$ & $\mathrm{R}$ & ni & ni & $\mathrm{R}$ & $\mathrm{R}$ & $\mathrm{R}$ & $\mathrm{R}$ & N/A \\
\hline \multirow[t]{2}{*}{ OC16 } & Clear cell ca & IC & + & $\mathrm{T}$ & $\mathrm{R}$ & $\mathrm{R}$ & ni & $\mathrm{R}$ & $\mathrm{R}$ & $\mathrm{R}$ & $\mathrm{R}$ & Neg \\
\hline & & & & W & $\mathrm{R}$ & $\mathrm{R}$ & ni & $\mathrm{R}$ & $\mathrm{R}$ & $\mathrm{R}$ & $\mathrm{R}$ & N/A \\
\hline \multirow[t]{2}{*}{ OC18 } & Yolk sac ca & IIIC & + & $\mathrm{T}$ & $\mathrm{R}$ & $\mathrm{R}$ & ni & ni & $\mathrm{R}$ & $\mathrm{R}$ & ni & Neg \\
\hline & & & & W & $\mathrm{R}$ & $\mathrm{R}$ & ni & ni & $\mathrm{R}$ & $\mathrm{R}$ & ni & N/A \\
\hline \multirow[t]{2}{*}{ OC3 } & Cystadenofibroma & & - & $\mathrm{T}$ & $\mathrm{R}$ & $\mathrm{R}$ & $\mathrm{R}$ & $\mathrm{R}$ & $\mathrm{R}$ & $\mathrm{R}$ & $\mathrm{R}$ & Neg \\
\hline & & & & W & $\mathrm{R}$ & $\mathrm{R}$ & $\mathrm{R}$ & $\mathrm{R}$ & $\mathrm{R}$ & $\mathrm{R}$ & $\mathrm{R}$ & N/A \\
\hline
\end{tabular}




\section{A $\quad$ OC2 D17S786}
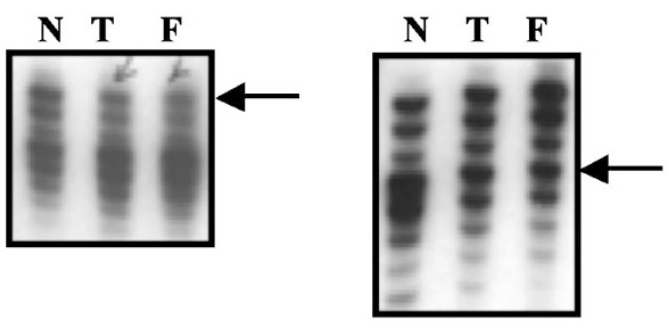

B

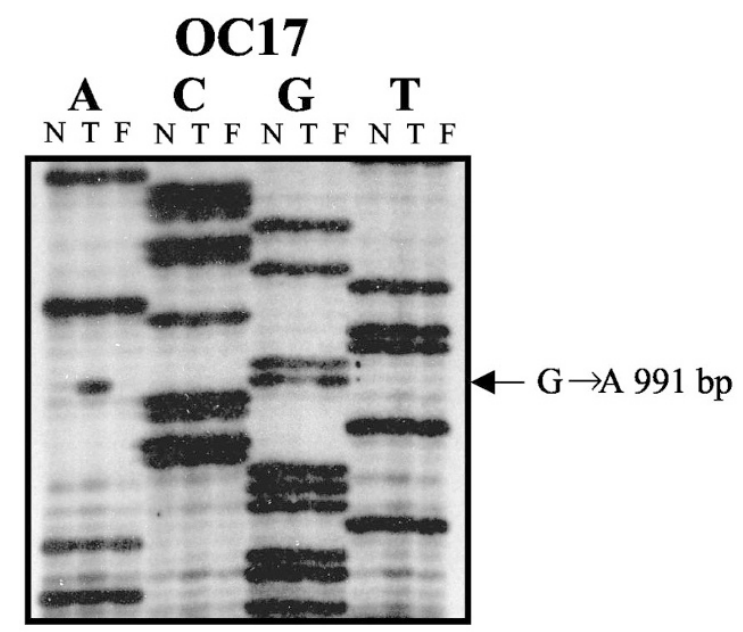

C

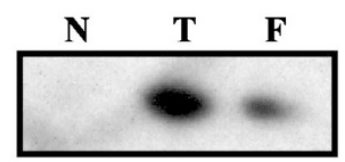

FIGURE 2. A, representative results of microsatellite marker analysis. Arrows indicate allelic loss. Tumor OC2 shows loss of heterozygosity (LOH) for a marker at the $p 53$ locus, and Tumor OC9 shows LOH for markers at the BRCA1 locus. B, manual sequence analysis of the $p 53$ gene. Tumor OC17 shows a base substitution at 991 bp in exon 7 (T). The mutation was not detected by this analysis in the corresponding peritoneal fluid specimen (F). C, oligonucleotide mismatch ligation assay for sample OC17. The specific oligonucleotides used for the analysis were discriminating oligonucleotide: 5'-CATGAACT-3' and wild-type oligonucleotide: 5'-GGAGGCC-3'. The ligation reaction shows the presence of a strong band in the tumor sample (T). A weaker band can be detected in the peritoneal fluid specimen (F). No band was detected in the corresponding DNA from normal blood lymphocytes (N).

velopment of novel and potentially powerful tools for clinical detection of this disease (22). Microsatellite analysis and specific point mutations have been used to detect tumor cells in tissue and fluids from various sources. Here we used a panel of nine molecular markers (seven microsatellite markers and $p 53$ and $K$-ras gene mutation analysis) to detect cancer cells in patients with primary ovarian tumors. The microsatellite markers chosen represented the most common altered loci in ovarian cancer according to published data. We found at least one molecular abnormality in $57 \%$ of the tu- mors tested but the frequency reaches $89 \%$ if only serous adenocarcinomas are considered. Of the eight patients with at least one alteration in the primary tumor, $5(62 \%)$ showed identical changes in matched peritoneal fluid.

In total $\mathrm{LOH}$ in at least one microsatellite marker was found in $28 \%$ of the ovarian cancers, and identical alterations could be detected in the peritoneal fluid sample in 3 cases (38\%; Table 1). No microsatellite instability was detected in our series. For tumors with $\mathrm{LOH}$ in more than one marker set, all showed the same pattern in the matched peritoneal fluid. In the only published (23) study that analyzed microsatellite abnormalities in peritoneal fluid from patients with ovarian cancer, the investigators reported $\mathrm{LOH}$ or microsatellite instability in approximately $60 \%$ of the cases. In the latter study, the authors used an automated fluorescent method with a cut-off for defining the $\mathrm{LOH}$ ratio of only $20 \%$, which may be responsible for their high positive rate.

Several studies indicate that serous adenocarcinoma has a high incidence of $p 53$ mutations as compared with other epithelial and non-epithelial ovarian tumors (24). We detected p53 mutations in $21 \%$ of the primary tumors tested, and all of them were serous adenocarcinoma. This result supports the hypothesis that inactivation of the $p 53$ tumor suppressor gene correlates with the histological type. Published data also indicate a difference in frequency of $K$-ras mutations among serous and mucinous adenocarcinoma, with a lower frequency in the serous subtype (30\% versus $60-85 \%)(11,25)$. Thus, the absence of $K$-ras mutations in our small cohort of samples, which was comprised of $>50 \%$ serous adenocarcinomas, is not completely surprising

Direct manual sequence analysis of the peritoneal fluid from patients with $p 53$ mutations was unable to detect the alteration in the corresponding peritoneal fluid. When we applied the more sensitive oligonucleotide mismatch ligation assay (26), the identical mutations were found in all three peritoneal fluids. This assay can detect one mutant cell among 1000 normal cells (26).

The ability to detect cancer by molecular analysis in bodily fluids depends mainly on the enrichment of tumor cells in the specimens. For example, microsatellite marker analysis allows the detection of tumor cells with high sensitivity and specificity in urine sediments from patients with bladder cancer $(18,19,26)$ but is much lower in specimens such as bronchoalveolar lavage from patients with lung cancer (27). The latter pulmonary specimens share with peritoneal fluid specimens the disadvantage of a substantial dilution of neoplastic cells caused by the presence of normal cells (e.g., inflammatory cells, peritoneal cells. The use of more sensitive 
detection methods, like the mismatch ligation assay used in this study, is likely to improve the sensitivity of detection of cancer cells in peritoneal fluid. Finally, more mutated oncogenes in ovarian cancer may allow the further application of this technique as a complement to current conventional diagnostic procedures for the detection of primary ovarian cancer.

\section{REFERENCES}

1. Landis SH, Murray T, Bolden S, Wingo PA. Cancer statistics. CA Cancer J Clin 1999;48:8-31.

2. Yancik R. Ovarian cancer: age contrasts in incidence, histology, disease stage at diagnosis and mortality. Cancer 1993; 71:517-23.

3. Creasman WT, Rutlege F. The prognostic value of peritoneal cytology in gynecologic malignant disease. Am J Obstet Gynecol 1971;110:773-8.

4. Tobias JS, Griffiths CT. Management of ovarian carcinoma. N Engl J Med 1976;294:818-23.

5. Motherby H, Nadjari B, Friegel P, Kohaus J, Ramp U, Bocking A. Diagnostic accuracy of effusion cytology. Diagn Cytopathol 1999;20:350-7.

6. Berchuck A, Heron KA, Carney ME, Lancaster JM, Fraser EG, Vinson VL, et al. Frequency of germline and somatic BRCA1 mutations in ovarian cancer. Clin Cancer Res 1998;4:2433-7.

7. Quezado MM, Moskaluk CA, Bryant B, Mills SE, Merino $\mathrm{MJ}$. Incidence of loss of heterozygosity at $p 53$ and BRCA1 loci in serous surface carcinoma. Hum Pathol 1999;30:203-7.

8. Foster KA, Harrington P, Kerr J, Russel P, DiCioccio RA, Scott IV, et al. Somatic and germline mutations of the BRCA2 gene in sporadic ovarian cancer. Cancer Res 1996;1996:56:3622-5.

9. Cliby W, Ritland S, Hartmann L, Dodson M, Keeney G, Podratz KC, et al. Human epithelial ovarian cancer allelotype. Cancer Res 1993;53:2393-8.

10. Teneriello MG, Ebina M, Linoilla I, Henry M, Nash JD, Park RC, et al. P53 and K-ras mutations in epithelial ovarian neoplasm. Cancer Res 1993;53:3103-8.

11. Cutrecasas M, Villanueva A, Matia-Guiu X, Prat J. K-ras mutation in mucinous ovarian tumors: a clinicopathological study of 95 cases. Cancer 1997;79:1581-6.

12. Kohler MF, Marks JR, Wiseman RW, Jacobs IJ, Davidoff AM, Clarke-Pearson DL, et al. Spectrum of mutation and frequency of allelic deletion of the $p 53$ gene in ovarian cancer. J Natl Cancer Inst 1993;85:1513-9.
13. Milner JJ, Allan LA, Eccles DM, Kitchener HC, Leonard RCF, Kelly KF. P53 mutation is a common genetic event in ovarian cancer. Cancer Res 1993;53:2128-2.

14. Kupryjanczyk J, Thor AD, Beuchamp R, Merrit V, Edgerton SM, Bell DA, et al. P53 gene mutations and protein accumulation in human ovarian cancer. Proc Natl Acad Sci U S A 1993;90:4961-5.

15. Boyd J. Molecular genetics of hereditary ovarian cancer. Oncology 1998;12:399-406.

16. Narod SA, Boyd J. Current understanding of epidemiology and clinical implication of BRCA1 and BRCA2 mutation in ovarian cancer. Curr Opin Obstet Gynecol 2002;14:19-26.

17. Parrella P, Xiao Y, Fliss M, Sanchez-Cespedes M, Mazzarelli $\mathrm{P}$, Rinaldi $\mathrm{M}$, et al. Detection of mitochondrial DNA mutations in primary breast cancer and fine needle aspirates. Cancer Res 2001;61:7623-6.

18. Mao L, Schoenberg MP, Scicchitano M, Erozan YS, Merlo A, Schwab D, et al. Molecular detection of primary bladder cancer by microsatellite analysis. Science 1996;271:659-62.

19. Steiner G, Schoenberg MP, Linn JF, Mao L, Sidransky D. Detection of bladder cancer recurrence by microsatellite analysis of urine. Nat Med 1997;3:621-4.

20. Hibi K, Robinson CR, Booke S, Wu L, Hamilt SR, Sidransky D, et al. Molecular detection of genetic alteration in the serum of colorectal cancer patients. Cancer Res 1998;58:1405-7.

21. Jen J, Powell SM, Papadopolous N, Smith KJ, Hamilto SR, Vogelstain B, et al. Molecular determinants of dysplasia in colorectal lesions. Cancer Res 1994;51:5523-6.

22. Sidransky D. Emerging molecular markers of cancer. Nat Rev Cancer 2002;2:210-9.

23. Hickey KP, Boyle KP, Jepps HM, Andrew AC, Buxton EJ, Burns PA. Molecular detection of tumour DNA in serum and peritoneal fluid from ovarian cancer patients. Br J Cancer 1999;80:1803-8.

24. Pieretti M, Powell DDE, Gallion HH, Case EA, Conway PS, Turker MS. Genetic alterations on chromosome 17 distinguish different types of epithelial ovarian tumors. Hum Pathol 1995;26:393-7.

25. Cuatrecasas M, Erill N, Musulen E, Costa I, Matias-Guiu X, Parat J. K-ras mutation in non-mucinous ovarian tumors: a molecular analysis and clinicopathologic study of 144 patients. Cancer 1998;82:1088-95.

26. Fliss MS, Usadel H, Caballero O, Wu L, Buta M, Eleff M, et al. Facile detection of mitochondrial DNA mutations in tumors and bodily fluid. Science (Wash DC) 2000;287:2017-9.

27. Ahrendt SA, Jow JT, Xu LH, Yang SC, Eisenberg CF, Esteller $\mathrm{M}$, et al. Molecular detection of tumor cell in bronchoalveolar lavage fluid from patients with early stage lung cancer. J Natl Cancer Inst 1999;91:332-9. 